\title{
Impacts of climate change on the agricultural zoning of climate risk for cotton cultivation in Brazil
}

\author{
Eduardo Delgado Assad(1), Susian Christian Martins ${ }^{(1)}$, Napoleão Esberard de Macêdo Beltrão(2) \\ and Hilton Silveira Pinto(3)
}

\begin{abstract}
(1)Embrapa Informática Agropecuária, Avenida André Tosello, no 209, CEP 13083-886 Campinas, SP, Brazil. E-mail: eduardo.assad@embrapa.br, susiancmartins@gmail.com (2)Embrapa Algodão, Rua Osvaldo Cruz, № 1143, CEP 58107720 Campina Grande, PB, Brazil. E-mail: napoleao.beltrao@embrapa.br ${ }^{(3)}$ Universidade Estadual de Campinas, Centro de Pesquisas Meteorológicas e Climáticas Aplicadas à Agricultura, Cidade Universitária Zeferino Vaz, CEP 13083-970 Campinas, SP, Brazil. E-mail: hilton@cpa.unicamp.br
\end{abstract}

\begin{abstract}
The objective of this work was to evaluate the effect of the temperature increase forecasted by the Intergovernmental Panel on Climate Change (IPCC) on agricultural zoning of cotton production in Brazil. The Northeastern region showed the highest decrease in the low-risk area for cotton cultivation due to the projected temperature increase. This area in the Brazilian Northeast may decrease from 83 million ha in 2010 to approximately 71 million ha in 2040, which means $15 \%$ reduction in 30 years. Southeastern and Center-Western regions had small decrease in areas suitable for cotton production until 2040, while the Northern region showed no reduction in these areas. Temperature increase will not benefit cotton cultivation in Brazil because dimension of low-risk areas for economic cotton production may decrease.
\end{abstract}

Index terms: Gossypium hirsutum, evapotranspiration, global warming.

\section{Impactos das mudanças climáticas no zoneamento agrícola de risco climático para o cultivo de algodão no Brasil}

\begin{abstract}
Resumo - O objetivo deste trabalho foi avaliar o efeito do aumento na temperatura, previsto pelo Painel Intergovernamental de Mudanças Climáticas (IPCC), sobre o risco climático para a produção de algodão no Brasil. O aumento previsto na temperatura fez com que a região Nordeste apresentasse a maior redução na área de baixo risco para cultivo de algodão, em comparação com as demais regiões do país. Essa área pode diminuir de 83 milhões de ha no ano de 2010 para aproximadamente 71 milhões de ha em 2040, o que significaria $15 \%$ de redução em 30 anos. As regiões Sudeste e Centro-Oeste apresentam pequena redução nas áreas aptas para o cultivo de algodão até 2040 , enquanto a região Norte não teve redução nessas áreas. A elevação das temperaturas não é benéfica para a produção do algodão no Brasil porque a área de baixo risco para o cultivo econômico pode diminuir.
\end{abstract}

Termos para indexação: Gossypium hirsutum, evapotranspiração, aquecimento global.

\section{Introduction}

In the last report of Intergovernmental Panel on Climate Change (IPCC), six different scenarios described the possible consequences of the increase of greenhouse gases (GHG) concentration in the atmosphere (Pachauri \& Reisinger, 2007). Besides temperature increasing, all scenarios showed acceleration in GHG emission rate. By the end of this century, considering these scenarios, a rise of temperature from $1.4^{\circ} \mathrm{C}$ (most optimistic scenario) to $5.4^{\circ} \mathrm{C}$ (most pessimist) is expected.

The cotton-planted area for 2010/2011 crop season in Brazil reached 1.400,3 million ha, 67.6\% higher than that of $2009 / 2010$, whereas cotton lint production increased 71.8\%(Companhia Nacional de Abastecimento, 2011).

Many studies have been done on the impacts of climate change on Brazilian agriculture, according to the predicted scenarios for regional climate (Zullo Júnior et al., 2006, 2011). Pinto (2008) concluded that global warming may risk cotton production in Brazil, if mitigating measures or adjustments are not taken. These authors show that crops may suffer with increased water deficiency and temperatures in regions where cotton is traditionally cultivated. They estimated a reduction of approximately $11 \%$ in areas with low risk for cotton cultivation, which may occur already in 2020 and reach around $16 \%$ in 2070, with negative economic impacts of $\mathrm{R} \$ 400$ million. 
Brazil has 3,590 municipalities with conditions for growing cotton with low-climate risk for crop. This amount may fall to 2,984 in 2070 , according to IPCC scenario B2, and to 2,967 as per scenario A2 (Pinto, 2008). By the A2 scenario, the best estimate temperature rises $3.4^{\circ} \mathrm{C}$ with a likely range from 2.0 to $5.4^{\circ} \mathrm{C}$; and in the $\mathrm{B} 2$ scenario, the best estimate temperature rises $2.4^{\circ} \mathrm{C}$ with a likely range from 1.4 to $3.8^{\circ} \mathrm{C}$ (Pachauri \& Reisinger, 2007). Climate zoning studies for herbaceous cotton, using different suitable criteria, were developed in some states and producer regions in the country (Beltrão et al., 2003). However similar studies for all states were not found; thus, an innovative character can be attributed to the present work. In this case, a longer climate series and a better tuning of climate models were employed, which allowed for more reliable results, as well as knowledge on the priority areas for investment in adaptation and mitigation of injury resulting from increased temperature.

The objective of this work was to evaluate the effect of the temperature increase forecasted by the Intergovernmental Panel on Climate Change (IPCC) on agricultural zoning of cotton production in Brazil.

\section{Materials and Methods}

The impacts of temperature increase on cotton agricultural zoning were evaluated with parameters of the Agricultural Zoning for Climatic Risk of the Ministério da Agricultura, Pecuária e Abastecimento (Ministry of Agriculture, Livestock, and Food Supply) (Amorin Neto et al., 2001; Assad et al., 2008). The following producing states were selected for evaluation: Alagoas, Bahia, Pernambuco, Piauí, Rio Grande do Norte, Tocantins, Goiás, Mato Grosso do Sul, Mato Grosso, Minas Gerais, and São Paulo. Agricultural scenarios of Brazil were simulated for 2010, 2020, 2030, and 2040, considering the perspective of global warming. Simulations started in 2010 to corroborate the early period of the National Policy on Climate Change (Law $n^{\circ} 12.187$ of 12/29/2009) and the publication of the Decree $n^{\circ} 7390$ of $12 / 09 / 2010$, of which the main goal is to reduce emissions of GHG.

The IPCC predictions were used for scenario A2, which estimates temperature increase between 2 and $5.4^{\circ} \mathrm{C}$ until 2100. Scenarios A2 and B2 showed no significant differences as to size projections of potentially cotton-producing areas until 2030. Future agricultural scenarios in Brazil were simulated by the Instituto Nacional de Pesquisas Espaciais (National Institute for Space Research, Inpe) using these temperatures. The projections of future scenarios of temperature increase were done by using the climatic model Precis (Providing Regional Climates for Impact Studies) (Alves \& Marengo, 2010), which is based on the climatic model HadRM3 developed by the Hadley Centre of the United Kingdom Meteorological Office (Johns et al., 2003). The Precis version used by Inpe's Centro de Previsão do Tempo e Estudos Climáticos (Center For Weather Forecast And Climate Studies, CPTEC) has a spatial resolution of $50 \times 50 \mathrm{~km}$, which allowed to verify with higher accuracy the impact of temperature increase in Brazilian agriculture. Temperature estimates for 2010, 2020, 2030 and 2040 were based on a linear regression of Precis simulations for each pixel of the domain, for two time periods: 1961-1990 and 2070-2100. Rain was not simulated because uncertainty is too large (Valverde \& Marengo, 2010).

The Agricultural Zoning of the present study considered cotton water balance (relation climate/soil/ plant) for 10-day periods using Sarra model (Affholder et al., 2006), and mathematical and statistical functions (frequency and probabilistic) to quantify crop loss risks based on previous adverse climatic events, mainly droughts. After analyzing meteorological data of historical series for each Brazilian state, the best time for sowing cotton was identified considering risk levels of yield reductions of up to $20 \%$. In order to simulate cotton water balance, the following parameters were considered: soil water retaining capacity (WRC), phenological phases duration, cycle duration, potential evapotranspiration (PTo), culture coefficient $\left(\mathrm{K}_{\mathrm{c}}\right)$, rainfall, air temperature, and the variation of this data set in the period. The potentially cotton production areas under risk in the national territory was obtained considering these criteria. The A2 scenario of temperature rise for 2010, 2020, 2030 and 2040 was introduced into this calculus.

Evapotranspiration was calculated by the Thornthwaite method (Thornthwaite, 1948) adapted for Brazilian conditions (Azevedo \& Silva, 2007), and water balance was determined according to Sarra model (Affholder et al., 2006), considering $50 \mathrm{~mm}$ of available soil water capacity. Monthly rainfall means 
were calculated considering daily values of 25 years, obtained from 4,000 rainfall stations, available in the Agritempo system (Brasil, 2012). Monthly average temperatures were mapped based on regression equations, with temperature as a function of latitude, longitude and altitude. Tables 1 and 2 showed the annual estimated temperature. These equations were developed for each state and for Northeastern region, with determination coefficients always higher than $80 \%$. Temperature data were also obtained from Agritempo, which has temperature records of about 1,200 meteorological stations in Brazil. Series were made with data of at least 15 years.

A culture cycle of 125 days was considered for water balance simulation, based on the relationships between air-basis temperature (Table 3) and degree-days necessary to complete the different phenological phases. Plant cycle was divided into four phenological phases: phase I, emergence (15 days); phase II, development (30 days); phase III, flowering/bud formation (45 days); and phase IV, maturation (35 days). Water demand is critical in flowering and bud formation phases (Dagdelen et al., 2006). Means for culture coefficient $\left(K_{c}\right)$ for 10-day periods were used according to Amorin Neto et al. (2001). The $\mathrm{K}_{\mathrm{c}}$ values used, in each ten-day period during the 125-day cycle, were: $0.30,0.40,0.50$, $0.70, \quad 0.90,1.20,1.00, \quad 0.90,0.70, \quad 0.60, \quad 0.50$, and 0.40. This information was added to the water balance model, for the simulations used to identify favorable sowing periods. Simulations were done every 10 days, from February to May, for the states of Alagoas, Bahia, Ceará, Paraíba, Pernambuco, Rio Grande do Norte and Sergipe. From October to December, these simulations were done for the states of Goiás, Maranhão, Minas Gerais, Mato Grosso do Sul, Mato Grosso, Piauí, São Paulo, Tocantins, Pará, and Distrito Federal.

For each date, the model estimated the water requirement satisfaction index (WRSI), defined as the relationship between real (ETr) and maximum (ETm) evapotranspirations for each phenological phase and for each meteorological station. In this matter, frequency functions were applied to obtain index occurrence frequency of $80 \%$. Values of WRSI calculated for each meteorological station were spatialized using a geographic information system (indication kriging), based on the methods described by Assad et al. (2003). For each possible planting date, a map was made to identify favorable and nonfavorable zones for cotton planting with the temperature changes estimated by climatic models. The following criteria were adopted using WRSI phase III: WRSI $\geq 0.55$, culture is exposed to lowclimate risk; and WRSI $\leq 0.55$, culture is exposed to high climatic risk.

Table 1. Values of the estimated parameters $\left(\beta_{0}, \beta_{1}, \beta_{2}\right)$ and coefficient of determination $\left(\mathrm{R}^{2}\right)$ fitted to average annual air temperature data for the analyzed states, in Brazil.

\begin{tabular}{|c|c|c|c|c|c|c|}
\hline \multirow[t]{2}{*}{ State } & \multicolumn{3}{|c|}{ Regression parameters } & \multirow[t]{2}{*}{ Multiple linear regression model ${ }^{(1)}$} & \multirow[t]{2}{*}{$\mathrm{R}^{2}$} & \multirow[t]{2}{*}{ Reference } \\
\hline & $\beta_{0}$ & $\beta_{1}$ & $\beta_{2}$ & & & \\
\hline Tocantins & 26.5795 & -0.0137 & -0.0039 & $\mathrm{~T}=26.5795-0.0137 \mathrm{Lat}-0.0039 \mathrm{Alt}$ & 0.86 & Embrapa Cerrados ${ }^{(2)}$ \\
\hline Goiás & 29.035 & -0.139 & -0.005 & $\mathrm{~T}=29.035-0.139 \mathrm{Lat}-0.005 \mathrm{Alt}$ & 0.89 & Embrapa Cerrados \\
\hline Mato Grosso & 26.0162 & -0.0041 & -0.0035 & $\mathrm{~T}=26.0162-0.0041$ Lat $-0.0035 \mathrm{Alt}$ & 0.63 & Embrapa Cerrados \\
\hline Mato Grosso do Sul & 32.9374 & -0.4205 & -0.0035 & $\mathrm{~T}=32.9374-0.4205$ Lat $-0.0035 \mathrm{Alt}$ & 0.92 & Embrapa Cerrados \\
\hline São Paulo & 38.98 & -0.005783 & -0.01125 & $\mathrm{~T}=38.98-0.005783 \mathrm{Lat}-0.01125 \mathrm{Alt}$ & 0.88 & Pinto et al. (1972) \\
\hline Minas Gerais & 26.62 & -0.005511 & -0.2718 & $\mathrm{~T}=26.62-0.005511 \mathrm{Lat}-0.2718 \mathrm{Alt}$ & 0.92 & Sediyama et al. (2001) \\
\hline
\end{tabular}

${ }^{(1)} \mathrm{T}=\beta_{0}+\beta_{1}$ latitud $+\beta_{2}$ altitud. ${ }^{(2)}$ Parameters generated at the Laboratório de Biofisíca Ambiental (Laboratory of Environmental Biophysics), Embrapa Cerrados.

Table 2. Regression coefficients for estimates of annual values of average air temperature in the states of Northeastern region and its coefficient of determination $\left(\mathrm{R}^{2}\right)$.

\begin{tabular}{lcccccccccccc}
\hline $\mathrm{R}^{2}$ & $\beta_{0}$ & $\beta_{1}$ & $\beta_{2}$ & $\beta_{3}$ & $\beta_{4}$ & $\beta_{5}$ & $\beta_{6}$ & $\beta_{7}$ & $\beta_{8}$ & $\beta_{9}$ & Equation \\
\hline 0.86 & 32.45762 & ns & -0.000006 & ns & -0.00297 & 1.87032 & ns & ns & ns & 0.04181 & T = A0 + A1Alt + A2Alt2 + A3Lon + A4Lon2 + A5Lat & Medeiros et \\
& & & & & & & & & & & + A6Lat2 + A7Alt $\times$ Lat + A8Alt $\times$ Lon + A9Lat $\times$ Lon & al. (2005) \\
\hline
\end{tabular}

Alt, altitud; Lat, latitud; Lon, longitud. 
Regarding the climatic risk classes, a municipality was considered suitable for cotton cultivation when at least $20 \%$ of its area showed WRSI higher than 0.55 (Amorim Neto et al., 2001). After that, previously obtained maps of temperature, precipitation, and altitude were cross-checked with the ten-day-period maps of water balance (ETr/ETm), in order to characterize low-climate-risk areas. The procedure previously described was developed year by year $(2010,2020,2030$ e 2040) in the scenario A2.

\section{Results and Discussion}

Temperature used in the Precis climatic model simulations (scenario A2) had a positive anomaly in the averages for all years and studied regions, compared to baseline 1961-1990 (Table 4). The observed monthly mean temperatures in 2010 are generally higher than the estimates made with Precis-Br for Brazil (Carvalho et al., 2011).

Temperature increase reduced the size of potential areas for cotton production, in the years 2020, 2030, and 2040 (Table 5), except in Northern region. This reduction is related to the temperature influence on evapotranspiration (Bezerra et al., 2012). Temperature increase is expected to enhance plant water demand, with direct influence on climatic risk. However, temperature increase reduces frost risk, which

Table 3. Temperature ranges for adequate cotton yield ${ }^{(1)}$.

\begin{tabular}{lccc}
\hline Phenological & \multicolumn{3}{c}{ Temperature $\left({ }^{\circ} \mathrm{C}\right)$} \\
\cline { 2 - 4 } stage & $\begin{array}{c}\text { Lower } \\
\text { threshold }\end{array}$ & Optimum & $\begin{array}{c}\text { Higher } \\
\text { threshold }\end{array}$ \\
\hline Germination & 14 & 18 to 30 & 40 \\
Vegetative development & 20 & 30 & 40 \\
Gems formation and flowering & Daytime 20 & 30 & Daytime 40 \\
Buds development and maturation & 20 & 27 to 32 & 38 \\
\hline
\end{tabular}

${ }^{(1)}$ Doorenbos et al. (1979).

Table 4. Simulation of temperature anomalies using the climatic model Precis (baseline 1961-1990) in scenario A2, for Brazilian cotton-producing regions, in the years 2010, 2020, 2030 and 2040.

\begin{tabular}{lcccc}
\hline Year & \multicolumn{4}{c}{ Projected temperature increase $\left({ }^{\circ} \mathrm{C}\right)$} \\
\cline { 2 - 5 } & Northern & Northeastern & Center-Western & Southeastern \\
\hline 2010 & 1.04 & 0.96 & 0.94 & 0.71 \\
2020 & 1.56 & 1.44 & 1.41 & 1.06 \\
2030 & 2.07 & 1.92 & 1.88 & 1.41 \\
2040 & 2.59 & 2.39 & 2.35 & 1.76 \\
\hline
\end{tabular}

could turn areas currently not suitable for cotton cultivation into favorable areas in the future. In this case, the climatic dynamics may cause the migration of this culture, which is adapted to tropical climate to southernmost areas of higher altitudes in the country (Pellegrino et al., 2007). The optimum range of the average air temperature for cotton satisfactory yields is between 20 and $30^{\circ} \mathrm{C}$ (Azevedo \& Silva, 2007). Bibi et al. (2008) reported that a high photosynthetic rate of cotton is expected at $32^{\circ} \mathrm{C}$, but net photosynthetic rate began to decrease from $22^{\circ} \mathrm{C}$. Temperature is also important for proper reproductive development (flowering and bud formation), as it has been clearly shown in cotton (Silva et al., 2011a).

The Northeastern region was responsible for the production of almost 2 million tons of cotton in 2010 (Companhia Nacional de Abastecimento, 2011). Due to the region importance for cotton production in Brazil, the impacts of temperature increase (Table 4) may undermine this culture yield. The temperature increase in the Northeastern region by scenario A2 caused the largest reduction of potentially cotton-producing low-risk area, according to the agricultural zoning of climatic risk, in comparison to other regions in Brazil (Table 5). Reduction of low-risk areas for crop production due to temperature increase have been reported in other studies (Pinto, 2008; Silva et al., 2012). All states of Northeastern region show a reduction in their low climate-risk areas for cotton production. The exception is the state of Maranhão, where all area shows low climate-risk until 2040. Silva et al. (2012) evaluated the impact of climate change on cotton grown in the Northeastern region, and observed that most of Maranhão would still have areas favorable for cotton cultivation even in the scenario with the increase in temperature of $5^{\circ} \mathrm{C}$. According to historical means of precipitation for Northwest region, Maranhão is the state with the highest net precipitation, which reduces the negative effects of temperature (Silva et al., 2011b).

Bahia state, the second highest cotton producer in Brazil, with 1,5 million tons of cotton seed in 2010 (Companhia Nacional de Abastecimento, 2011), showed the largest reduction in low climate-risk area for cotton cultivation, mainly in its western section, reaching $75.10 \%$ in 2040 (Table 5). The countryside of this state has a semi-arid climate, and precipitation hardly reach $500 \mathrm{~mm}$ per year. Therefore, the trend 
of rising temperature shows a worsening in drought situation. Tanajura et al. (2010) compared the results of HadRM3P in the scenarios A2 and B2 with the present climate simulation, and found that there was a reduction of precipitation and an increase in 2-m temperature across Bahia state. The same spatial pattern of 2-m temperature changes and of rainfall was simulated for both scenarios, but with larger magnitudes for the A2. The authors reported that the largest reduction of annual rainfall was observed in the coast (about $70 \%$ ), in both scenarios, and that temperature increase was greater in the northwest and north (about $5^{\circ} \mathrm{C}$ for A2 and $4^{\circ} \mathrm{C}$ for B2). Annual rainfall would decrease between 20 and $60 \%$ in the A2 scenario, and between 20 and $50 \%$ in the B2 scenario. The largest increases in air temperature were shown for northwest and north of the state, in approximately $5.5^{\circ} \mathrm{C}$ (A2) and $4.5^{\circ} \mathrm{C}$ (B2). In the coast, increases were between 2 and $3.5^{\circ} \mathrm{C}$ (A2), and between 1.5 and $2.5^{\circ} \mathrm{C}$ (B2). These results are consistent with those found in the present study.

The development of cotton genetic variants, more suitable for high temperatures and water deficit, can be an alternative for responding to climate change
(Silva et al., 2012). Genetic changes could minimize the constraints imposed to crops by temperatures up to $2{ }^{\circ} \mathrm{C}$ above the average. This increase in temperature is projected to be achieved in 2030 in the Northeastern region (Table 4). Above this limit, photosynthesis would be strongly compromised. Development of second generation transgenic plants might be the alternative in this case. Besides being tolerant to herbicides, or resistant to insects, these plants are more adapted to environmental stresses (Freire et al., 2008).

Compared to the other regions, the anomaly projected for average air temperature was the highest for Northern region (Table 4), which corroborates the observation by Valverde \& Marengo (2010). In the fourth IPCC annual report, warming in the Northern region, mainly in the southern Amazon, can reach up to $5^{\circ} \mathrm{C}$ by 2100 (Pachauri \& Reisinger, 2007). The state of Tocantins is the only cotton producer in the Northern region, but its production is low: 20 thousand tons in 2010. However, the state area with low climate-risk for cotton cultivation was not reduced in the scenario A2 until 2040 (Table 5). Annual rainfall is high in Tocantins. Keller Filho et al. (2005) observed

Table 5. Areas with low-climatic risk for cotton cultivation in Brazil, accordingly to the simulations made for the years 2010 , 2020, 2030 and 2040, with the A2 scenario.

\begin{tabular}{|c|c|c|c|c|c|c|c|c|c|}
\hline \multirow[t]{2}{*}{ State } & \multirow{2}{*}{$\begin{array}{c}\text { Total area } \\
\text { (ha) }\end{array}$} & \multicolumn{2}{|c|}{ Low-risk area 2010} & \multicolumn{2}{|c|}{ Low-risk area 2020} & \multicolumn{2}{|c|}{ Low-risk area 2030} & \multicolumn{2}{|c|}{ Low-risk area 2040} \\
\hline & & (ha) & $(\%)$ & (ha) & $(\%)$ & (ha) & $(\%)$ & (ha) & $(\%)$ \\
\hline & \multicolumn{9}{|c|}{ Northeast region } \\
\hline Alagoas & $2,776,845$ & $2,218,914$ & 79.88 & $2,196,874$ & 79.08 & $2,182,212$ & 78.56 & $2,168,701$ & 78.07 \\
\hline Bahia & $56,469,319$ & $9,682,774$ & 17.14 & $5,424,305$ & 9.60 & $4,273,558$ & 7.57 & $2,411,451$ & 4.27 \\
\hline Ceará & $14,882,627$ & $13,564,809$ & 91.09 & $13,153,886$ & 88.33 & $12,747,011$ & 85.60 & $12,174,282$ & 81.75 \\
\hline Maranhão & $33,190,735$ & $33,190,736$ & 100 & $33,190,735$ & 100 & $33,190,735$ & 100 & $33,190,735$ & 100 \\
\hline Paraíba & $5,644,070$ & $2,792,787$ & 49.46 & $2,851,972$ & 50.50 & $2,834,877$ & 50.20 & $2,638,990$ & 46.73 \\
\hline Pernambuco & $9,831,067$ & $2,486,189$ & 25.33 & $1,156,074$ & 11.78 & $1,114,658$ & 11.36 & 963,784 & 9.82 \\
\hline Piauí & $25,152,884$ & $18,528,399$ & 73.65 & $17,485,943$ & 69.51 & $17,791,552$ & 70.72 & $16,897,627$ & 67.17 \\
\hline Rio Grande do Norte & $5,279,786$ & $1,090,734$ & 20.65 & 873,866 & 16.55 & 863,869 & 16.36 & 797,710 & 15.11 \\
\hline \multirow[t]{2}{*}{ Total } & $153,227,331$ & $83,555,341$ & 54.53 & $76,333,657$ & 49.82 & $74,998,476$ & 48.95 & $71,243,287$ & 46.50 \\
\hline & \multicolumn{9}{|c|}{ Northern region } \\
\hline Tocantins & $27,762,268$ & $27,762,268$ & 100 & $27,762,268$ & 100 & $27,762,268$ & 100 & $27,762,268$ & 100 \\
\hline \multirow[t]{2}{*}{ Total } & $27,762,268$ & $27,762,268$ & 100 & $27,762,268$ & 100 & $27,762,268$ & 100 & $27,762,268$ & 100 \\
\hline & \multicolumn{9}{|c|}{ Center-Western region } \\
\hline Goiás & $34,008,545$ & $33,656,066$ & 98.96 & $33,667,496$ & 98.99 & $33,628,512$ & 98.88 & $33,377,143$ & 98.14 \\
\hline Mato Grosso do Sul & $35,712,443$ & $20,502,107$ & 57.41 & $19,399,956$ & 54.32 & $18,018,700$ & 50.45 & $16,937,611$ & 47.42 \\
\hline Mato Grosso & $90,335,942$ & $68,539,293$ & 75.87 & $69,051,360$ & 76.44 & $68,834,256$ & 76.20 & $67,507,156$ & 74.73 \\
\hline \multirow[t]{2}{*}{ Total } & $160,056,930$ & $122,697,463$ & 76.66 & $122,118,813$ & 76.30 & $120,481,468$ & 75.27 & $117,821,910$ & 73.61 \\
\hline & \multicolumn{9}{|c|}{ Southeastern region } \\
\hline Minas Gerais & $58,652,896$ & $45,875,523$ & 78.22 & $45,110,261$ & 76.91 & $44,982,679$ & 76.69 & $44,241,186$ & 75.43 \\
\hline São Paulo & $24,820,766$ & $24,819,696$ & 100 & $24,819,696$ & 100 & $24,819,696$ & 100 & $24,819,696$ & 100 \\
\hline Total & $83,473,662$ & $70,695,219$ & 84.69 & $69,929,957$ & 83.77 & $69,802,375$ & 83.62 & $69,060,882$ & 82.73 \\
\hline
\end{tabular}


an average annual rainfall between 1,000 to $1,500 \mathrm{~mm}$. Since the projected temperature increase in the scenario A2 (Table 4) will not likely cause enough water deficiency to threaten cultivation in the state (Table 5), cotton has a high potential to have its cropping area in Tocantins enhanced in the upcoming years; especially considering the reduction of low climate-risk areas in other currently important cotton-producing regions in the country. Therefore, Tocantins can overcome the production of some Northeastern states, such as Bahia.

The Southeastern region, which produced 200 thousand tons of cotton in the crop season of 2010/2011 (Companhia Nacional de Abastecimento, 2011), had the lowest increase in the projected average air temperature between 2020 to 2040 (Table 4), and a little reduction in its cotton-producing area with low climate-risk (Table 5). The states of Minas Gerais and São Paulo had a distinct behavior as to their low-risk areas. The state of Minas Gerais had its suitable areas for cotton production reduced in $3.56 \%$ in 2040, while São Paulo did not show any reduction in its suitable areas, probably due to the higher and better distributed rainfall in the state, compared to Minas Gerais (Keller Filho et al., 2005). The north of Minas Gerais is a transition zone for the Northeastern region climate, with an average maximum annual rainfall of $1,100 \mathrm{~mm}$ (Keller Filho et al., 2005).

Cotton is a culture of great economic importance in the Brazilian Center-Western region. The projected temperature increase in this region was of $2.35^{\circ} \mathrm{C}$ (Table 4 ), which caused $4 \%$ reduction in its low-risk area for cotton cultivation (Table 5). According to the IPCC projections (Pachauri \& Reisinger, 2007), the average global temperature may increase $2.0^{\circ} \mathrm{C}$ in the next 20 years. The Center-West is the main cotton-producing region in the country, reaching approximately 3.5 million tons in the crop season of 2010/2011 (Companhia Nacional de Abastecimento, 2011). The state with the largest reduction in suitable areas was Mato Grosso do Sul, a result related to the frequent dry spells that occur in the state, mainly in the Dourados Municipality and vicinities (Arai et al., 2009). Dry spells in the state may become more intense with the temperature elevation projected for 2020 to 2040, which may further reduce suitable municipalities for cotton planting, according to the agricultural zoning of climatic risk. The state of Mato Grosso, the largest Brazilian cotton producer, with
2.6 million tons in the crop season of 2010/2011, may have only a slight decrease $(1.5 \%)$ in its suitable area for cotton production. This result is due to the regular rainfall distribution during sowing months (October to December), and to a relatively high rainfall (greater than $1,500 \mathrm{~mm}$ ) during culture development period (Keller Filho et al., 2005). Goiás state showed the same behavior as Mato Grosso.

\section{Conclusions}

1. Low-risk areas for cotton cultivation are expected to decrease in Brazil, according to the Precis' model simulation for A2 scenario.

2. Northeastern region may be the most affected region by the projected temperature increase.

3. Center-Western and Southeastern regions may be the less affected ones.

\section{Acknowledgements}

To the Centro de Previsão de Tempo e Estudos Climáticos (CPTEC), from Instituto Nacional de Pesquisas Espaciais (Inpe), for the projections of future scenarios of temperature increase; to the Bristish Embassy for the partial funding, and to the Conselho Nacional de Desenvolvimento Científico e Tecnológico (CNPq) for the grants.

\section{References}

AFFHOLDER, F.; ASSAD, E.D.; BONNAL, P.; SILVA, F.A.M. da; FOREST, F.; NETTO, J.M.; SCOPEL, É.; CORBEELS, M. Risques de stress hydrique sur les cultures dans les Cerrados brésiliens du zonage régional à l'analyse des risques à l'échelle des exploitations familiales. Cahiers Agricultures, v.15, p.433-439, 2006.

ALVES, L.M.; MARENGO, J. Assessment of regional seasonal predictability using the PRECIS regional climate modeling system over South America. Theoretical and Applied Climatology, v.100, p.337-350, 2010. DOI: 10.1007/s00704-009-0165-2.

AMORIM NETO, M. da S.; ARAÚJO, A.E. de; CARAMORI, P.H.; GONÇALVES, S.L.; WREGE, M.S.; LAZZAROTTO, C.; LAMAS, F.M.; SANS, L.M.A. Zoneamento agroecológico e definição da época de semeadura do algodoeiro no Brasil. Revista Brasileira de Agrometeorologia, v.9, p.422-428, 2001.

ARAI, F.K.; GONÇALVES, G.G.G.; PEREIRA, S.B.; PEIXOTO, P.P.P. Estudo do comportamento pluvial na região de Dourados, MS. Agrarian, v.2, p.105-112, 2009.

ASSAD, E.D.; MACEDO, M.A. de; ZULLO JÚNIOR, J.; PINTO, H.S.; BRUNINI, O. Avaliação de métodos geoestatísticos na 
espacialização de índices agrometeorológicos para definir riscos climáticos. Pesquisa Agropecuária Brasileira, v.38, p.161-171, 2003. DOI: 10.1590/S0100-204X2003000200001.

ASSAD, E.D.; MARIN, F.R.; PINTO, H.S.; ZULLO JÚNIOR, J. Zoneamento agrícola de riscos climáticos do Brasil: base teórica, pesquisa e desenvolvimento. Informe Agropecuário, v.10, p.1-10, 2008.

AZEVEDO, P.V. de; SILVA, F.D. dos S. Risco climático para o cultivo do algodoeiro na região Nordeste do Brasil. Revista Brasileira de Meteorologia, v.22, p.408-416, 2007. DOI:10.1590/ S0102-77862007000300012

BELTRÃO, N.E. de M.; ARAÚJO, A.E. de; BENASSI, A.C.; AMARAL, J.A.B. do; SEVERINO, L.S.; CARDOSO, G.D. Zoneamento e época de plantio para o algodoeiro no Norte do Estado do Espírito Santo. Revista Brasileira de Engenharia Agrícola e Ambiental, v.7, p.99-105, 2003. DOI:10.1590/S141543662003000100016.

BEZERRA, B.G.; SILVA, B.B. da; BEZERRA, J.R.C.; SOFIATTI, V.; SANTOS, C.A.C. dos. Evapotranspiration and crop coefficient for sprinkler-irrigated cotton crop in Apodi Plateau semiarid lands of Brazil. Agricultural Water Management, v.107, p.86-93, 2012. DOI: $10.1016 /$ j.agwat.2012.01.013.

BIBI, A.C.; OOSTERHUIS, D.M.; GONIAS, E.D. Photosynthesis, quantum yield of photosystem II and membrane leakage as affected by high temperatures in cotton genotypes. Journal of Cotton Science, v.12, p.150-159, 2008.

BRASIL. Ministério da Agricultura, Pecuária e Abastecimento. Agritempo: sistema de monitoramento agrometeorológico. Disponível em: <http://www.agritempo.gov.br/>. Acesso em: 4 fev. 2012.

CARVALHO, J.R.P. de; ASSAD, E.D.; PINTO, H.S. Kalman filter and correction of the temperatures estimated by PRECIS model. Atmospheric Research, v.102, p.218-226, 2011. DOI: 10.1016/j. atmosres.2011.07.007.

COMPANHIA NACIONAL DE ABASTECIMENTO. Acompanhamento da safra brasileira: grãos safra 2010/2011 décimo segundo levantamento. Brasília: Conab, 2011. 40p.

DAGDELEN, N.; ERSEL, Y.; SEZGIN, F.; GURBUZ, T. Water-yield relation and water use efficiency of cotton (Gossypium hirsutum L.) and second crop corn (Zea mays L.) in western Turkey. Agricultural Water Management, v.82, p.63-85, 2006. DOI: 10.1016/j.agwat.2005.05.006.

DOORENBOS, J.; KASSAN, A.H.; BENTVELSEN, C.L.M.; BRANSCHEID, V.; PLUSJÉ, J.M.G.A.; SMITH, M.; UITTENBOAGAARD, G.O.; VAN DER VAL, H.K. Efectos del agua sobre el rendimiento de los cultivos. Roma: FAO, 1979. $212 \mathrm{p}$.

FREIRE, E.C.; MORELLO, C.L.; FARIAS, F.J.C.; SILVA FILHO, J.L.; VIDAL NETO, F.C.; PEDROSA, M.B.; SUINAGA, F.A.; COSTA, J.N.; ANDRADE, F.P. Objetivos e métodos usados nos programas de melhoramento do algodão. In: BELTRÃO, N.E. de M.; AZEVEDO, D.M.P. (Ed.). O agronegócio do algodão no Brasil. $2^{\text {nd }}$ ed. Brasília: Embrapa Informação Tecnológica, 2008. p.299-323.
JOHNS, T.C.; GREGORY, J.M.; INGRAM, W.J.; JOHNSON, C.E.; JONES, A.; LOWE, J.A.; MITCHELL, J.F.B.; ROBERTS, D.L.; SEXTON, D.M.H.; STEVENSON, D.S.; TETT, S.F.B.; WOODAGE, M.J. Anthropogenic climate change for 1860 to 2100 simulated with the HadCM3 model under updated emissions scenarios. Climate Dynamics, v.20, p.583-612, 2003.

KELLER FILHO, T.; ASSAD, E.D.; LIMA, P.R.S. de R. Regiões pluviometricamente homogêneas no Brasil. Pesquisa Agropecuária Brasileira, v.40, p.311-322, 2005. DOI: 10.1590/ S0100-204X2005000400001.

MEDEIROS, S. de S.; CECÍLIO, R.A.; MELO JÚNIOR, J.C.F. de; SILVA JÚNIOR, J.L.C. da. Estimativa e espacialização das temperaturas do ar mínimas, médias e máximas na região Nordeste do Brasil. Revista Brasileira de Engenharia Agrícola e Ambiental, v.9, p.247-255, 2005. DOI: 10.1590/S141543662005000200016.

PACHAURI, R.K.; REISINGER, A. Climate change 2007: synthesis report. Contribution of Working Groups I, II and III to the Fourth Assessment Report of the Intergovernmental Panel on Climate Change. Genebra: IPCC, 2007. 104p.

PELLEGRINO, G.Q.; ASSAD, E.D.; MARIN, F.R. Mudanças climáticas globais e a agricultura no Brasil. Revista Multiciência, n.8, p.139-162, 2007.

PINTO, H.S. (Coord.). Aquecimento global e a nova geografia da produção agrícola no Brasil. Campinas: Unicamp; Brasília: Embrapa, 2008. 82p.

PINTO, H.S.; ORTOLONI, A.A.; ALFONSI, R.R. Estimativa das temperaturas médias mensais do Estado de São Paulo em função da altitude e latitude. São Paulo: Universidade de São Paulo, 1972. 19p. (Caderno de Ciências da Terra, 23).

SEDIYAMA, G.C.; MELO JÚNIOR, J.C.F. de; SANTOS, A.R. dos; RIBEIRO, A.; COSTA, M.H.; HAMAKAWA, P.J.; COSTA, J.M.N. da; COSTA, L.C. Zoneamento agroclimático do cafeeiro (Coffea arabica L.) para o Estado de Minas Gerais. Revista Brasileira de Agrometeorologia, v.9, p.501-509, 2001.

SILVA, I.P.F.; JUNIOR, J.F.S.; ARALDI, R.; TANAKA, A.A.; GIROTTO, M.; BOSQUÊ, G.G.; LIMA, F.C.C. Estudos das fases fenológicas do algodão (Gossypium hirsutum L.). Revista Científica Eletrônica de Agronomia, v.10, 2011a. Disponível em: $<$ http://www.revista.inf.br/agro20/artigos/Revisao_5.pdf $>$. Acesso em: 01 fev. 2012.

SILVA, M.T.; SILVA, V. de P.R. da; AZEVEDO, P.V. de. O cultivo do algodão herbáceo no sistema de sequeiro no Nordeste do Brasil, no cenário de mudanças climática. Revista Brasileira de Engenharia Agrícola e Ambiental, v.16, p.80-91, 2012. DOI: 10.1590/S1415-43662012000100011

SILVA, V.P.R. da; PEREIRA, E.R.R.; AZEVEDO, P.V. de; SOUSA, F. de A.S. de; SOUSA, I.F. de. Análise da pluviometria e dias chuvosos na região Nordeste do Brasil. Revista Brasileira de Engenharia Agrícola e Ambiental, v.15, p.131-138, 2011b. DOI: 10.1590/S1415-43662011000200004.

TANAJURA, C.A.S.; GENZ, F.; ARAÚJO, H.A. de. Mudanças climáticas e recursos hídricos na Bahia: validação da simulação do clima presente do HadRM3P e comparação com os cenários A2 e B2 para 2070-2100. Revista Brasileira de Meteorologia, v.25, p.345-358, 2010. DOI: 10.1590/S0102-77862010000300006. 
THORNTHWAITE, C.W. An approach toward a rational classification of climate. Geographical Review, v.38, p.55-94, 1948. DOI: $10.2307 / 210739$.

VALVERDE, M.C.; MARENGO, J.A. Mudanças na circulação atmosférica sobre a América do Sul para cenários futuros de clima projetados pelos modelos globais do IPCC AR4. Revista Brasileira de Meteorologia, v.25, p.125-145, 2010. DOI: 10.1590/ S0102-77862010000100011.
ZULLO JUNIOR, J.; PINTO, H.S.; ASSAD, E.D. Impact assessment study of climate change on agricultural zoning. Meteorological Applications, v.13, p.69-80, 2006. DOI: 10.1017/ S135048270600257X.

ZULLO JUNIOR, J.; PINTO, H.S.; ASSAD, E.D.; ÁVILA, A.M.H. de. Potential for growing Arabica coffee in the extreme South of Brazil in a warmer world. Climatic Change, v.109, p.535-548, 2011. DOI:10.1007/s10584-011-0058-0.

$\overline{\text { Received on August 1st, } 2012 \text { and accepted on January 3, } 2013}$ 